\title{
The Use of Games to Foster Fluency among ESL Learners
}

\author{
Aylar Fallah Vazirabad ${ }^{1}$ \\ ${ }^{1}$ University of Essex, UK \\ Correspondence: Aylar Fallah Vazirabad, University of Essex, UK. E-mail: aylarfallahvazirabad@yahoo.com
}

\author{
Received: January 21, 2013 Accepted: February 26, 2013 Online Published: March 26, 2013 \\ doi:10.5539/ies.v6n4p205 URL: http://dx.doi.org/10.5539/ies.v6n4p205
}

\begin{abstract}
This study focused on five particular Communication Strategies (CSs) namely: Paraphrase, approximation, hesitation, reduction, borrowed words and invented, or anglicised. The aim was to investigate the link between the use of approvable and positive CS-types and the impact of ESL students' beliefs about CSs in a game-activity. It aims to promote students fluency based on positive CSs. The study used a series of videoed and transcribed task-observations based on 'Spot the Differences' information-gap activities. In addition, the views and beliefs of 6 teachers and 6 students were sampled using structured interviews. The results interestingly revealed that hesitation was one of the most approved and positive strategies. The teacher interviews revealed that the more experienced teachers focused attention on fluency and helping student to 'keep going', and using all types of CSs while less experienced tutors focused attention on both fluency and vocabulary learning in communication tasks. Less experienced teachers also uttered that hesitation and reduction strategies should not to be encouraged and it is better that teacher tell the word if student needs it or paraphrase them. The observation also highlighted that there is a relation between the teacher's inner beliefs and the student's fluency level. Data from the videoed observations revealed that body language was an important element in communicating meaning. The results also revealed what strategies these teachers encourage students to use in a communication activity. That are mostly avoided because of their misconception about a communication activity. Analysis of CSs also showed the link between teacher and students beliefs about approvable CSs and their level of achieved fluency.
\end{abstract}

Keywords: games, communication strategies, fluency in the English language, communicative ability, ESL

\section{Introduction}

Celce-Murcia and Macintosh, (1979), state that in games, language-use takes precedence over language-practice, and games bring the student closer to the real-world situation through its task-oriented characteristics. Most of the researchers, however, believe that adult learners require a language if they are involved in a real and meaningful language environment (Alemi, 2010).

The literature on CSs is replete with contradictory findings. Researchers such as Tarone (1980), Faerch and Kasper (1980), Maleki (2007) believe that during usage of time-gaining strategies [here, hesitation fillers] students are not utilizing words and they are just hesitating, so that they have not mentioned this CS types as a tool to foster fluency. Several other researchers, however, have highlighted the significance of using Fillers and Hesitation devices as a means to remain in communication in the face of difficulties (Canale, 1983; Canale \& Swain, 1980; Ellis, 1985; Hasstrup \& Phillipson, 1983).

Besides, Avoidance strategies would also fall short of qualifying as real CSs because by using them, one's meaning is not negotiated but reduced. Williems (1987) identifies them as Reduction CSs, and views them as negative, whereas, other researchers believe that topic Avoidance and Replacement-skills could improve a learner's fluency reinforcing the old view that 'Language learners should be encouraged to say what they can rather than retreat silently from what they can't'. While one put explanation in paraphrasing CSs, the other considers it in a different category. As an example, Corder (1981) divided CSs into two groups: message adjustment and resource expansion strategies. Other researchers such as Faerch and Kasper, 1983; Ellis, 1985 have used different terms: reduction and avoidance strategies for the first, and achievement strategies for the second. Willems (1987) also divides them into receptive and productive. In sum there is clearly a need to provide what strategies teachers believe as productive and positive in real classes, among teachers and students. 
In addition, despite the significant amount of educational research and the growing interest in CSs, there is a lack of practical research on the negative or positive effects of CSs in a fluency activity. According to Willems (1987) article, CSs are divided in to two kinds: positive (achievement/compensatory) or negative (reduction strategies). So for example in one of its subcategories which is Message abandonment, learner avoids using the word by changing the topic, e.g. 'Let's talk about how the other part of the 'filtering machine' works' rather than talking about that part of the machine. But Faerch and Kasper categorize it as a positive CS type. In language classrooms, learners are producing CSs. On the other hand, the main objective of language learning is to be the learners' ability to communicate in real-world situations, which in turn requires serious attention to be paid to various types of CSs (Willems, 1987). However, this investigation and the outcome advise that a general plan is required to affect a fundamental change in the teacher's and student's belief. Given such a necessity, the present study is intended to provide a clear picture of the strategies that teachers and students need to know in fostering fluency. This study clearly shows how this belief affects the students and teachers' perspective on the game. It also highlights the beliefs on CSs that play an affective role in promoting fluency through a game-activity.

Goals might be powerful motivators. Learners who do set appropriate goals and beliefs seem to sustain their learning (here, fluency) (Ames, 1992 and Dweck, 1991, cited in Clark, 2007). Games, of course, are linked with goals, and require specific beliefs and strategies. Research has sought to investigate the root of goal-setting. It appears that the learner's thoughts, beliefs and efforts have been the fundamental contributing factors to goal-setting (Kanfer, 1992).

We should be aware of disapproval or approval factors within the student's speech act, and within the teacher's and student's own beliefs (Mowrer, 1960, cited in Clark, 2007). There should be an in-depth observation and investigation into these factors so that we can come to a definite conclusion on how games foster fluency when a student is doubtful or has a misconception about using appropriate CS type. Thus this is important to reveal what type of strategies are considered as positive and the impact of teacher's belief on students and also the effect of student's previous beliefs on their success or failure in communicating and fostering fluency.

\section{Purpose of the Study}

The research's goal as discussed earlier is to categorize effective CSs based on student's productivity and experienced teachers beliefs that made the students fluent. Therefore, we developed four main questions:

- What types of CSs the students at intermediate level use when engaged in information-gap activity?

- Does teacher and student's self-belief, have an influence on students use of CSs?

- Is hesitation a positive or negative strategy?

- Is reduction a positive or negative strategy?

\section{Method}

\subsection{Participants}

Six students participated in this study. They were students from pre-sessional classes all from University of Essex. The participants in this study represented adult intermediate level international students who were studying English to improve their English before starting a degree. They are between 18- 24 years old. Overall, they had an IELTS score of 5.0-5.5. The teacher participants were the class tutors of the student participants. Teachers who were interviewed were from the same university and taught pre-sessional students. They were all British, native speakers of English. One was male and the rest were female. Teacher A and B have 3 years teaching experience. Teacher $\mathrm{C}$ has 4 years of experience. Teacher D taught English for 7-8 years. While Teacher $\mathrm{E}$ and $\mathrm{F}$ have 10 years and 20 years teaching experience, respectively.

\subsection{Instruments and Data Collection}

\subsubsection{Systematic Video Recording of Information-Gap Task}

In this study, we video recorded students during the task-based activity. The aim was to notice consciously and very detailed observation of the participant's behavior in a natural setting. In this study, observation took place among pairs working on the information-gap activity and after class hours. They were seating in pairs. Each volunteer in pair work had a separate picture. The partner had a similar picture with a few differences on each of them. Each pair had 20-25 minutes to communicate and spot the differences. Focus was on individuals and in pair activity. The video recording and analysis of CSs were related to individual students rather than the whole class. Participants were volunteers coming from the six-mentioned teacher's classes. They were also took part in interview section. The sights, sounds, gestures and mimes of students while doing an activity, even their silence, led us to know what type of CSs was used. In fact, it was a systematic observation, and aimed to produce 
qualitative data, which were pre-coded and were ready to analyze. Observation was used by accompanying with other methods of data collection to triangulate or provide additional evidence for a research study; therefore, teacher and student interviews were also done.

\subsubsection{Interviews}

We utilized semi-structured interviews that were a number of questions written as the main research questions, while adding prompts to have freedom to ask additional questions if needed. The teacher interview questions are as follows:

\section{Teacher Interview Questions}

1) How long have you been teaching English?

2) What is your point of view about using hesitation? (such as hmmm, eee)

3) Do you teach them hesitation devices? ( such as: well, you know, I see)

4) Do your students know how kind of communication strategies they are not allowed to use? (such as hesitation- mother tongue sentences - mother tongue words - saying I do not know.)

5) Do you think they know which one of the above mentioned strategies they are not allowed to use?

6) What is your opinion about using 'I don't know' in an 'Information gap' activity?

7) What is your opinion about changing the topic if students do not know the exact word?

8) Do you teach them Communication Strategies?/ (prompt: Do you believe in teachability of Communication activities?)- paraphrase, approximation, Non-linguistic means, reduction strategies, smurfing)

9) Are there anything else you would like to add to this interview section?

\subsection{Data Analysis}

This study was composed of quantitative and qualitative analyses. Systematic observation through video recording while students were doing an activity, was analyzed and all CSs were coded. All student speech was recorded and then were typed, and then each utilized CS type in their speech was highlighted. Then the number of occurrences were calculated and added to the list of specific category. For example, Non-linguistic means were used in a student's speech for 101 times. Then the numbers were mentioned and highlighted to be compared with other strategy and in the attached table. However as far as this research is concerned, I will be using the combination of the most popular terms by my own definitions and based on the purpose and relation to this study. Moreover, List of the CS categories are also attached into Appendix 1. Quantitative part of this study was done through calculating frequency of different types of CSs and then qualitative part was done by analyzing the observed data as well as the interview parts.

\section{Results and Discussion}

As mentioned earlier, this study was aimed at designing a specific code system for analysing CSs. The quantitative part in means of frequency is shown in Table 1. It provides a brief overview of the analyses, and the different categories are illustrated in a colour scheme.

Table 1. Video-recorded analysis of students communication strategies

\begin{tabular}{|c|c|c|c|c|c|c|c|c|}
\hline $\begin{array}{l}\text { Analysis of CS } \\
\text { Use Among } \\
\text { Students }\end{array}$ & $\begin{array}{lc}\text { SA } & \text { SB } \\
\text { Syria-m } & \text { Iran- } \\
\text { ale } & \text { Female }\end{array}$ & $\begin{array}{l}\text { SC } \\
\text { Japan- } \\
\text { Male }\end{array}$ & $\begin{array}{l}\text { SD } \\
\text { Japan- } \\
\text { Female }\end{array}$ & $\begin{array}{l}\text { SE } \\
\text { Italia- } \\
\text { Female }\end{array}$ & $\begin{array}{l}\text { SF } \\
\text { Saudi } \\
\text { Arabia- } \\
\text { Female }\end{array}$ & $\begin{array}{l}\text { WHOLE } \\
\text { GROUP }\end{array}$ & $\begin{array}{l}\text { Group } \\
\text { A } \\
\text { (purple) }\end{array}$ & $\begin{array}{l}\text { Group } \\
\text { B (pink) }\end{array}$ \\
\hline
\end{tabular}

A. Paraphrase

A1.Paraphrase-

Definition

A2.Paraphrase-

Description

A3.Approximati

on

1

$7 \quad 12$

12

0

1

0

5

3

2

B. Hesitation

B1.Hesitation with Filler

4 0

0

5

3

17

14 


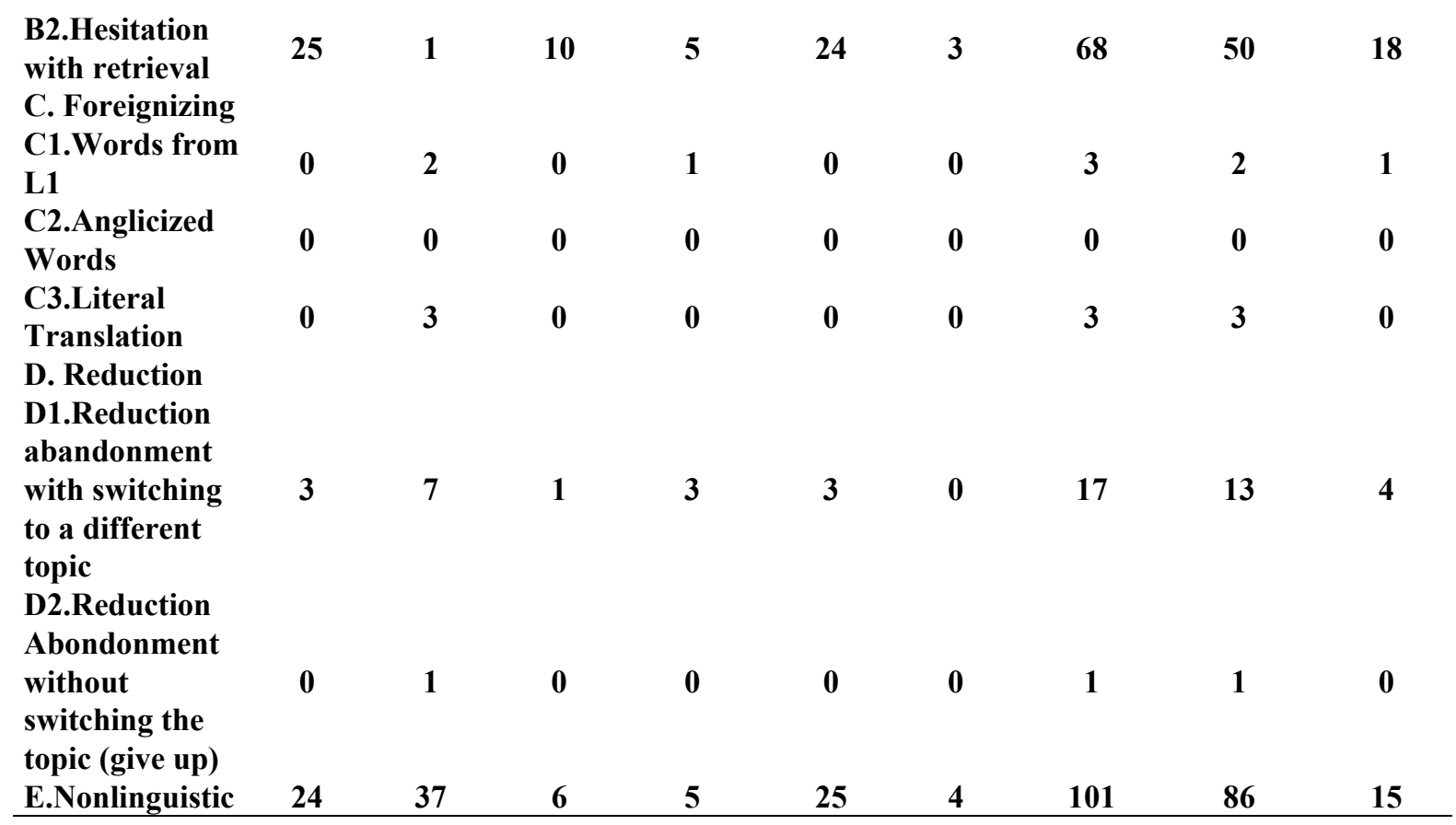

\subsection{Teacher and Student Interviews}

In the qualitative part, teachers and students interviews were analyzed. A total number of six teachers were interviewed for this study. All are British speakers of English. The most significant difference between them is their teaching experience: teachers A, B, and C having taught ESL for 3 years, teacher D for 7-8 years, teacher E for 10 years and teacher $\mathrm{F}$ having 20 years.

The results indicate that teachers tended to have different views on the balance between promoting CSs and stepping into providing more language. Teacher $\mathrm{D}, \mathrm{E}$, and $\mathrm{F}$ who are the most experienced have positive comments on hesitation, and paraphrasing. Conversely, teacher A, B, and C are more concerned to teach vocabulary as means of promoting fluency. These teachers are more worried by hesitation, and do not report paraphrasing. Moreover, the following Table gives a summary of a brief student and teacher interviews:

Table 2. A brief student and teacher interviews

\begin{tabular}{|c|c|c|c|c|c|}
\hline $\begin{array}{l}\text { A Summary of } \\
\text { Student } \\
\text { Interview }\end{array}$ & HESITATION & REDUCTION & $\begin{array}{l}\text { A Summary of } \\
\text { Teacher } \\
\text { Interviews }\end{array}$ & HESITATION & $\begin{array}{l}\text { REDUCTION/ } \\
\text { TEACHER } \\
\text { SUGGESTIONS }\end{array}$ \\
\hline Student A & $\begin{array}{l}\text { If it gives you } \\
\text { time to think, } \\
\text { why not. Only } \\
\text { in exams, they } \\
\text { want to test us. }\end{array}$ & $\begin{array}{l}\text { Prefers to define } \\
\text { a word rather } \\
\text { than use 'I } \\
\text { don't know' }\end{array}$ & Teacher A & $\begin{array}{l}\text { Not to be } \\
\text { encouraged }\end{array}$ & $\begin{array}{l}\text { Completely } \\
\text { acceptable/ Its } \\
\text { teachers } \\
\text { responsibility to } \\
\text { paraphrase }\end{array}$ \\
\hline Student B & $\begin{array}{l}\text { Focuses on } \\
\text { learning new } \\
\text { words and } \\
\text { believes that } \\
\text { hesitation } \\
\text { should be } \\
\text { avoided, I do } \\
\text { not like to talk } \\
\text { fast without } \\
\text { following } \\
\text { grammar, or }\end{array}$ & $\begin{array}{l}\text { If I don't know I } \\
\text { ask the word. }\end{array}$ & Teacher B & $\begin{array}{l}\text { Common and } \\
\text { Acceptable }\end{array}$ & $\begin{array}{l}\text { A cry for } \\
\text { attention/ } \\
\text { Vocabulary } \\
\text { should be taught } \\
\text { before the } \\
\text { activity }\end{array}$ \\
\hline
\end{tabular}


correct words

\begin{tabular}{|c|c|c|c|c|c|}
\hline Student C & $\begin{array}{l}\text { Focuses on } \\
\text { learning new } \\
\text { words and } \\
\text { believes that } \\
\text { hesitation } \\
\text { should be } \\
\text { avoided, I do } \\
\text { not like to talk } \\
\text { fast without } \\
\text { following } \\
\text { grammar, or } \\
\text { correct words }\end{array}$ & $\begin{array}{l}\text { I prefer to deny } \\
\text { hesitation, it is } \\
\text { not good, If I } \\
\text { don't know I } \\
\text { ask the word. } \\
\text { Unfortunately, } \\
\text { the teacher } \\
\text { helped me with } \\
\text { defining a word } \\
\text { or telling me the } \\
\text { word but they } \\
\text { don't tell me } \\
\text { exactly what to } \\
\text { do to define a } \\
\text { word. }\end{array}$ & Teacher C & It's a good sign & $\begin{array}{l}\text { Student should } \\
\text { find the answer } \\
\text { not the teacher }\end{array}$ \\
\hline Student D & $\begin{array}{l}\text { Has never been } \\
\text { told about } \\
\text { hesitation, } \\
\text { sometimes } \\
\text { hesitation is } \\
\text { fluency }\end{array}$ & $\begin{array}{l}\text { Asks for words } \\
\text { rather than } \\
\text { reduction, but it } \\
\text { not good when } \\
\text { you just say } \\
\text { nothing. We are } \\
\text { allowed to use } \\
\text { hesitation }\end{array}$ & Teacher D & $\begin{array}{l}\text { A good learning } \\
\text { tool }\end{array}$ & $\begin{array}{l}\text { Willing to make } \\
\text { suggestions }\end{array}$ \\
\hline Student E & $\begin{array}{l}\text { It is better to } \\
\text { know the exact } \\
\text { word. Hesitation } \\
\text { has negative } \\
\text { impact. It means } \\
\text { you do not } \\
\text { know proper } \\
\text { vocabulary }\end{array}$ & $\begin{array}{l}\text { Try to say } \\
\text { something } \\
\text { instead of } \\
\text { reduction. } \\
\text { Teachers never } \\
\text { teach us } \\
\text { hesitation } \\
\text { devices during } \\
\text { my language } \\
\text { lessons in my } \\
\text { life }\end{array}$ & Teacher E & $\begin{array}{l}\text { Encourages her } \\
\text { partner to help }\end{array}$ & $\begin{array}{l}\text { Encourages } \\
\text { students to } \\
\text { paraphrase }\end{array}$ \\
\hline Student F & $\begin{array}{l}\text { I try to use exact } \\
\text { word...if I don't } \\
\text { know... I } \\
\text { apologize... I } \\
\text { prefer to say...I } \\
\text { don't know } \\
\text { when I don't } \\
\text { know the exact } \\
\text { word and never } \\
\text { define words }\end{array}$ & $\begin{array}{l}\text { I apologize and } \\
\text { say I do not } \\
\text { know anything. } \\
\text { It is not bad. I } \\
\text { ask the teacher } \\
\text { and in most of } \\
\text { the cases } \\
\text { teacher says the } \\
\text { word }\end{array}$ & Teacher F & $\begin{array}{l}\text { Hesitation } \\
\text { means that they } \\
\text { are thinking }\end{array}$ & $\begin{array}{l}\text { Not mentioned } \\
\text { teacher input }\end{array}$ \\
\hline
\end{tabular}

With regard to the interviews with the students, however, the results also revealed that SA displayed a positive attitude towards CSs, including Hesitation. SB also had a positive disposition towards CSs - preferring to define a word rather than using 'I don't know'. However, SC tended to focus on learning new words and believed in avoiding hesitation. Similarly, SD and SE maintained that it is better to know the exact word, while SF asserted, 'I try to use the exact word...if I don't know... I apologize...I prefer to say... I don't know ...rather than define words'. She also believes that the goal of a game-activity, especially the goal of a fluency activity, can be achieved if she pays attention to her speech-errors. She adds: 'I did not have self-confidence when I played the game-activity because I was worried about my speech errors. I was not capable of saying everything fluently, 
even if the instructor told me to just speak and not pay attention to the errors. Well, our teacher normally corrects us. We normally ask the teacher. I personally do not like to fail, so I keep silent and let the teacher help. There is no fun in the game-activity after all'. SA, on the contrary, believes that: 'I like being involved in the game-activity. After all, what is important is to try to be independent. If I do not know a word, I try to paraphrase. I do not think that hesitation is a sign of failing. I like the competition, and I really enjoyed the fun of finding the differences, no matter how. I liked the challenge in the game-activity. I am very confident, and try not to depend on the teacher's instructions. I can do it by myself in most cases'.

\subsection{Review of Observation and Interviews}

The systematic observation of students in this study reveals the fact that students used various types of CSs to convey their meaning. While this revealed to be true, analysis of CSs usage shows that students generally used body language more than other types of strategies and as the most practical strategy among students and from teacher interviews.

The second highly useful strategy is hesitation and among the two types of hesitation, HES-RET was highly used, this conveys the meaning that students used any kind of strategies to convey their meaning to their partner and not to be silenced. In contrary, HES_Fill even though was used less than HES-RET, but still is one of the most used type of CS.

Paraphrasing is the third highly useful strategy; PARA-DESC, approximation, and PARA-DEF are used respectively. Paraphrasing also is described as a very good strategy among teachers, although there are different point of views about it, and will be discussed under the next hypothesis. Reduction strategy is considered as one of the less popular strategies.

Applied linguistics determines development of CSs as an evidence for learner's fluency and conversational skills (Dornyei and Thurrel, 1991). This is clearly seen among half of the students in this study, however the other half do not meet this criteria, and it could be obviously observed in the video-recorded section. The students are namely S3 and S4 from Japan, and student 6 from Saudi Arabia, which their CS usages can be seen in CS analysis section and in the separate bar designed for each group, below:

Based on interview with teacher A: ....if they give a list of synonyms they can look around it, and then find the word.... Or if not in that moment I clarify with them did you mean that you are looking for a word that means this? \& if they say yes, I will give them more, but if they say no, I will say try to describe this word again. \& they go back to same cycle that either they guess on their own or they convince me with the word and I provide them with that.

For Teacher A if student do not know a word describes it or give synonym herself, and do not expect it from the student to do paraphrasing. If students could not guess the meaning, she herself provides students with the word itself in a communication activity.

Teacher B however has a different point of view:

“...maybe they are asking for a different learning style, or a different teaching approach. \& then you should find a different approach with this learner \& address their learning needs, because they are maybe are bringing a learning style that are bringing from school or somewhere, where the teacher spent lots of time with them. They may had a teacher who explained the words on wall, gave definition, and wanted less from students. So you should try to change their styles a little bit....As a teacher you are aware of it. So maybe they are not adapted to new communicative approach, because maybe they bring their style from 10 years, 8 years agoes style, so better to adapt them to new style. I don't know, I think it is cry for help."

This statement is supported, by Little (1995) that sometimes teachers should focus on the cognitive demands of the communicative tasks our learners need to master rather than their previews perceived learning styles for a successful task performance. However, how to master and lead learners in this success seem to be a 'grey area' that this hypothesis answers.

He also adds this point that:

“...Well, you should pre-told \& taught the vocabulary.... as a teacher you have to think on your feet, that you missed something in your plan...So if this vocabulary is not known, ....I think you should pre-plan it, and pre-teach all vocabulary beforehand. So its all about good preparation."

Although this might be an appropriate approach, but as a reply against this statement, emphasizing in communication and fluency improvement, and as quoted in the literature, River (1981) argues that through language learning memorized vocabulary might be forgotten while having spontaneous speech, so students who 
encounter a real communication situation seems that need to use CS, for an unpredictable situation in the time of speaking.

Teacher C: We believe in letting them to have their own mistakes...communication is just to be understood, if you made a mistake it doesn't really matter in communication, because people just keep going with all these things. So its hard to teach that but ...then you can try to promote these methods.

This statement also is supported, when the focus is on communication and not correctness to use CS to convey their meanings (Ellis, 1984). However, it does not give depth knowledge about the method used to lead students to gain the new learning style.

Teacher C, paraphrases and summaries, and gives them the exact word just after describing the word herself. She believes in having cognitive reasoning by students and trying to describe the words by them, but does not emphasize it too much. She also believes that not attempting to try to convey meaning will lead to the lack of opportunity in having fluency.

On the contrary, teacher D believes that:

...I normally ask them can you describe or can you tell us a sense of what that means. As an example what's the other word for this... or what were the other words for this. Saying them, what do you mean? for understanding. Suppose can you give us an example? Or you can say can you look it up in your dictionary and let us know ...I suppose looking at dictionary should be the last option. If they really couldn't find it I just told them just look it up and to see what the dictionary gives the definition. Then once we had a definition, and then I talked about it some more.

It shows that the last option of teacher D is the first option of the three first teachers. She emphasized on paraphrasing, and explanation of a word rather than an exact word. Her last option might be looking up in dictionary but it happens very rarely. By looking at dictionary, she wants them to see the exact word but also the definition.

Finally, one of the two experienced EFL teacher, teacher E describes that:

...Well, I try to get them to say anything about it, just saying something, doesn't need to be perfect. Don't be shy, or something like that...I guess sometimes when you are doing a game, you just want some language to be produced.

Her ideas convey the meaning that she does not focus on exact word. What she really wants in the game activity is to let them produce speech without being sensitive about perfection. She suggests using some strategies:

...I tell them if you do not know the exact word can you describe the function of it, what is it, in a general class, to take some objects that they might not know those words in English, such as driver, employers or something, and get them to get the other person to guess it. Someone has a picture of a can opener, and explains it, that it is something to open the things...I ask them just to say anything they know about the object, the color or something. You know help your partner and even you could ask him questions to help them.

It seems that the controvert belief of this teacher from other less experienced teachers arises by experience, and is influenced in her teaching as well. Even though still it is vague how students in this class might learn to be fluent compared to the previews students. But it seems that experience plays a fundamental role. Teachers should be experienced by natural process to promote students fluency or rather to be taught to do it.

The most experience EFL teacher, however says:

...Talking about problems of fluency I mean speaking fluently is somewhat difficult in speaking foreign language. I think it is with processing difficulties. I think if you are speaking, you are very aware of the other person, and what they need, and you are also trying to teach grammar and vocabulary. So there is sort of a lot of things going on, I think actually it is difficult to be, to achieve both fluency and accuracy, I think something has to go usually. \& one way I give that to students is to be quiet explicit about that, and if they are doing an speaking activity, to say that do try to be fluent, if we are focusing on fluency or we are focusing on accuracy. It seems that it is challenging to be accurate that causes the problems of accuracy. Sometimes I think it's good to keep going, just to go with the kind of speed, and focus about the mistakes later. Therefore, if you are constantly worried about having mistakes, it leads to pauses that can cause problems. So that's one thing I do, really to make people think about what's going on and actually it's a very ambitious thing to be both fluent and accurate.

She also suggested story-telling designs and speech bubbles as a support for communication activities and as a support for the spot the difference activity: 
I think peoples mind are designed to be story-telling mind. To tell stories, so I think if you can encourage doing narrative that encourages people to be fluent as well. If this is something that personally happened to you then it's deeply meaningful \& it's easy, it's easier if you can talk about it to be fluent about something like that. The activities, because they know that subject matter, as the subjects matters itself. Actually when I am teaching, I use speech bubbles with things: like having spell, how do you say this in English. You know all those kind of words that help them to be more independent, and to find the information themselves... there are some cardboards, and there are bubbles, all around them, how do you spell, how do you ... and learn how to use those questions, how do you spell that, how do you define that word. To help them learn how to ask those questions.

To make this argument clear that why some students do not use CS and therefore, have fluency problem, we divided students into two groups. The first group is student $1,2,5$, which used CS a lot, and student 3 , 4, and 6 who did not use CS, in contrary, and to match them with teacher's point of view:

Student A- I try to find synonym for it, I try to find other words to describe what I want, use my hands to point to something related to, anything that help me..., to say the definition of the word. If I don't know the exact word I try to say the definition of it. My teachers can help me to say what word I am looking for.

“...Communication Activities. Sometimes we talk about, about daily life things. When we go to shops when we try to buy stuff for ourselves. When we have friendly speech not in the main course only when we have friendly speech we, they teach about these stuff. Because they normally speak and they normally use these strategies, so we learn from them. When you are learning from talking from native speaker, it's a normal, you learn normally from it."

All this strategies overlap with the strategies that experienced teacher E and F used to use. As we discussed earlier during teacher discussion section, teachers also are divided in to two, the ones who emphasized teaching exact words and the experienced teachers who in fact believe in just conveying meaning. The last teacher believes in story-telling, and this student also had to use it as a technique.

Student $\mathrm{E}$ also adds that:

... Or I can explain with a phrase. If I do not know the meaning of table, I can explain like, it's a place I can put my stuff, my paper or my pen, in another way....sometimes I use invented words. Sometimes when I don't know what to say I try to invent a word.

In conveying her meaning student $\mathrm{E}$ even uses invented words which is quiet weird to be used by students who believe in using the exact word. Student E mentions that:

... teachers divide us into groups like making a cross word. You have to speak about the meaning of the word. The other group has to guess the word, but if they can't guess they normally use dictionary. To have some advice how to play the meaning of the word. If they do not know the word you also may do some drawing.

On the contrary, the students who lack fluency to a large extent prefer not to have any attempt to define what they want to convey:

...I will ask the persons, I mean others. Yes. Maybe if I have a dictionary or a dictionary machine, I will give that dictionary to that person so to say look person and give me the word. \& what it means.... Using synonym. Because you know that it has meaning, or it has a synonym, but easy words.

Student $\mathrm{C}$ directly asks the word, or uses dictionary, just he uses synonyms sometimes, even though they might use paraphrasing but not very appropriate ones which can be again seen in analysis section and in appendix.

Student D:

...Yes, teacher more explains about the vocabulary. Yes, to how to use a vocabulary. She tells us the differences between vocabularies, and it's meaning. Just google it....Maybe I check in dictionary or ask someone for word meaning. I do not use any other strategies, I just directly ask them....Teacher told us when we don't know some words, just ask the teacher. Or imagine the words meaning from the sentences. Checking the word, using dictionary is very easy.

Student $\mathrm{F}$, even just and just emphasized that uses exact word, by saying:

...I prefer to have exact word.... sometimes I made a mistake but I don't like...

Her teacher suggests that:

you can build up your vocabulary, as much as possible. ..you can then easily communicate with people. 
According to our arguments, it seems to me that there is a correlation between teachers experience and students fluency. Student 1,2, and 5 show lots of CSs and fluency in their conversation, interview also revealed that their teacher prefer fluency rather than correctness or using exact word in a communication activity. On the contrary, student 3, 4, and 6 believe mostly on using exact words based on influence of their teacher's notion.

Table 1 shows that the number of Hesitations used generally is more than other CSs in this study. In both cases all hesitations used are from simple hesitation types such as: [hmmm, aaaa, yeeeeeees, deeeeeeeeesk...]

The interview with the teachers shows that all teachers are satisfied with student's hesitation and they call it as natural, common and useful tools.

Teacher $\mathrm{C}$ even pointed out that:

"I think it' ok. I think when one uses hmmm, that looks someone is thinking..."

It is also mentioned that even if students are not able to retrieve words in this level that is fine, because it is the process of their learning.

To support this notion however Dornyei states that:

The ability to use fillers and hesitation devices plays an important role in helping a person to remain in the conversation and gain time to think; we have found in the past that teaching fillers brings about an improvement in students' fluency. (1995)

However, Canale (1983) specifically listed the 'use of pause fillers among the CSs making up strategic competence. Haastrup and phillipson (1983) included in their taxanomy a set of strategies which they termed 'strategies aimed at solving retrieval problems' (e.g., 'er now I have to think'), Rost (1994) also mentions using conversational fillers to keep the conversation going in his list of communication strategies. However, whether to use this devices instead of simple hesitation devices was always questioned among researchers. The interview with teachers seems to support this view that teachers are not quite sure how to promote this strategies but all of them except one are interested to use them.

Interestingly teacher A mentions that:

...." I think hesitation or a pause is something fine because if you substitute those words with Hesitation Devices, I think they might think those phrases are preferable so I think I haven't."

It seems that the teacher can substitute those words by clarifying that they are facilitators and could mention that they are not preferable speech devices.

In contrary, Teacher B thinks that:

“.... I think if they are using them, they are good signs of fluency. In my experience, I never taught that. But I think its interesting because using hesitation techniques to give you time to think about an answer means you are a very strong learner..."

Teacher $\mathrm{C}$ adds to this point that:

“...It gives them the feeling of human being, instead of feeling like robot. But I never taught about it, but I can see how might be useful... Maybe you want to say: hmmm, let me think about that. \& let your audience know, you are not just...interesting point. Let's consider that. Because if they just keep silent they might, it might look awkward. So I see how useful it might be. \& I think after they speak it is better to tell them you can use them.

Teacher E points out:

...hmm it depends, like very formal hesitation devices, for example students who have to defend their Viva in this university, they should know phrases like aaa that's a good question. You know meaningless phrases to give them a couple of seconds to think. I think they are good devices if they are employed correctly.... Well, because they are usually rather specific phrases, we just teach them the word chunk as it were. To say when to use them, when it is appropriate. Practice with them talking etc. But students should be aware because they normally do not have those devices. We do not usually teach, the textbooks normally do not teach them.

On the other hand, interview with students shows that student A is the only exception to use Hesitation Devices, which using the Hesitation Devices was obviously seen while he was talking to me in the interview section (using hesitation devices such as well), he mentioned that:

'....Well, I use hesitation ( $\mathrm{hmm}$, eee) sometimes, it gives me the time to think. It's ok to use it, why not....So we don't focus usually on communication skills which help us in our daily life.... I learned Hesitation Devices from TV. Not from any English class, from movies. 
Interviewer) So you were taught about them? Or...? Did you have it in your coursework?

No, no I just listen to them in media, movies films, maybe friends. A lovely movie.

The interview with him clarified the fact that he used the hesitation devices, but formal hesitation devices and not the ones for games or informal speech. He mentioned that he learned them by listening to media, movies or friends.

Interestingly, student $\mathrm{C}$ was the exception to say that:

“.....Hesitation is not good for fluency. I think but we are allowed to use hesitation, its not compulsory."

Students $\mathrm{C}$ even do not agree to have fluency. And he uses HES_Fill and HES-RET against his belief.

It is significantly useful to mention that all students used HES-Fill and HES-RET in the game activity, and all mentioned in the interview that having hesitation has a good impact; even hesitation as very long pauses is not recommended. However, all of them mentioned that Hesitation Devices were not taught or told by their teachers, but they seem willing to be taught or know them.

As another significant statement, student D also uttered this statement about Hesitation Devices that:

“...I never been told such as these words, But I want to use these words because I think when I use these words the conversation become more fluency. But in Japan using these words is not good. So our culture don't use these words, so I can't use these hesitation words. We I mean use hesitation words but people don't use these words such as not a good speaker. It's negative thing in my country."

It supports the belief that highlighting cross-cultural differences in CS use might be very significant, as in some languages particular CSs may be seen as indications of bad style (Dornye, 1995)

Other students believe that hesitation is a positive communication activity, unless until it is used for very long pauses, which show students, lack of knowledge and should be avoided.

If this is the case that HES-Fill \& HES-RET are being used 42 and 68 times respectively as one of the most useful and fundamental communication tool and none of them in the game activity included the Hesitation Devices, then this seems to be an area in which there could be improvement. As students have never focused on using them in an informal setting such as a game activity, it is evidence that students may lack the appropriate hesitation devices to use as strong language learners.

Student $\mathrm{C}$ also is from a sample of six students and it might mean that some students generally do not believe hesitation as a natural communication tool, so they should be told about it, even though in this analysis he used hesitation naturally and in a number of times.

In addition, for student $\mathrm{D}$, it seems ideal to remember cultural differences as well as other issues.

Therefore, the students who believe that they should use the exact word do not have fluency in a Communication Activity.

Teachers and students believe that having HES_FILL \& HES-RET is a good communication strategy, but they are unsure of how to promote Hesitation Devices.

The interview with teachers shows that generally using reduction strategies [I do not know] is seen as an unproductive strategy among students:

Teacher D: .... when you say I don't know that's ok, but just do try to say something else, too.

Teacher E: ... Maybe I try to get them to say anything about it hhh just saying something, doesn't need to be perfect, Don't be shy, or something like that.

There is however, a correlation between teacher's belief and students interview answers and what they really did in real conversational setting:

Student C: ...If I say I don't know, first I try, instead of saying it....

Student D: I say [I don't know... but....] to keep conversation going...

Interestingly we can see the correlation between what teachers and students believe are similar and students do believe that using reduction strategies are allowed but because it is not productive they try to try and do their best to convey their meanings by other means. Therefore, mostly they use REDUC-ABAN-SW instead of REDUC-ABAN-0.

\section{Conclusion}


Results from this study shows that students and teachers believe that hesitation is a natural and common tool that shows someone is thinking. And even if students are hesitation without retrieval we should let them do it, as it is the process of learning and thinking about how to convey their meanings and should not be interrupted. Students, however, are hesitating many times in their speech, and all teachers and students except one teacher would like to teach and learn hesitation devices, to facilitate students thinking process. Interview with students revealed that teachers are not utilizing them as helpful strategies. One student learned them in media, and movies. One teacher also uses formal hesitation devices in presentation sessions, but how she teaches them was quiet vague. She also mentioned the lack of these devices in their textbooks. One teacher also uses it during game activity and telling how to use it, directly. However, there was no systematic strategy mentioned, through game activity.

The interviews revealed that teacher experience has an impact on student's fluency. Experienced teachers prefer students to be free from vocabulary learning during a communication activity. They use other activities such as story telling, or bubble game that focuses on vocabulary paraphrasing and fluency rather than structure, correctness or learning the exact vocabulary. Student 5 also mentioned using cross word in class as a definition and paraphrasing activity. They never mention vocabulary learning in a fluency activity. This promotes their students fluency, while on the other hand students who believe to learn both vocabulary and fluency, correctness and fluency in the same way, prefer not to make mistakes are under the influence of teachers which believe in teaching exact vocabulary while communication or after communication activity and as a feedback. This teacher seems to avoid the role of paraphrasing and using communication strategies, which is mentioned by experienced teachers.

On the other hand, this study revealed that there is a correlation among all teachers and students about avoidance strategies. It seems that all teachers had an influence on students, and on not using 'I don't know'. If they do not know a word, they try their best, in most of the cases. It also shows that most of the students prefer to communicate rather than just say 'I don't know'. Most of the teachers let their students to communicate freely.

Body language seems to be used as the most useful and fundamental strategy among students, and seems to have a positive impact on conveying meaning, however it seems that there is a correlation between students who lack fluency and the frequency of using body language. Hesitation is the next most useful strategy and later paraphrasing strategies. Students used reduction strategies, and mostly tried to convey their meanings even after that. Foregnizing strategy however, could not be tested based on lack of comparable pairs of students from same L1 country. However, invented and anglicized strategy could be tested and seems that no one used them. Overall, the research revealed a relationship between teacher and students belief on their communication abilities. The more experienced teacher's students were fluent compared to the students who believed that communication strategies such as hesitation devices is better to be avoided.

\section{References}

Alemi, M. (2010). Utilizing game-based learning to develop vocabulary knowledge: Utilizing game words, LAP LAMBERT Academic Publishing, Germany.

Canale, M. (1983). From communicative competence to communicative language pedagogy. In Richards, J. C., \& Schimidt, R. (Eds.), Language and Communication. New York: Longman

Canale, M., \& Swaine, M. (1980). Theoretical bases of communicative approaches to second language teaching \& testing. Applied Linguistics, 1, 1-47. http://dx.doi.org/10.1093/applin/1.1.1

Celcel-Murcia, M., \& Macintosh, L. (1979). Teaching English as a second or foreign language, 241-257. Rowley, Ma.: Newbury House.

Clark, D. (2007). Games, motivation and learning. Caspian learning, engaging minds. Retrieved from http://www.caspianlearning.co.uk/Whtp_Games_Motivation_Learning.pdf.

Corder, S. P. (1981). Error analysis and interlanguage. Oxford: Oxford University Press.

Dörnyei, Z. (1995). On the teachability of communication strategies. TESOL Quarterly, 29, 55-85. http://dx.doi.org/10.2307/3587805

Dornyei, Z., \& Thurrell, S. (1991). Strategic competence and how to teach it. ELT Journal, 45, 16-23. http://dx.doi.org/10.1093/elt/45.1.16

Ellis, R. (1985). Understanding second language acquisition. Oxford: Oxford University Press.

Faerch, C., \& Kasper, G. (1980). Process and strategies in foreign language learning and communication. Interlanguage Studies Bulletin, 5, 47-118. 
Faerch, C., \& Kasper, G. (Eds). (1983). Strategies in Interlanguage Communication. Longman.

Haastrup, K., \& Phillipson, R. (1983). Achievement strategies in learner/native speaker interaction. In C. Faerch, \& G. Kasper (Eds.), Strategies in interlanguage communication (pp. 140-158). New York: Longman Inc.

Kanfer, R. (1992). Work motivation: New directions in theory and research. In C. L. Cooper, \& I. T. Robertson (Eds.), International review of industrial and organizational psychology (Vol. 7, pp. 1-53). New York: Wiley.

Little, D. (1995). Learning as dialogue: The dependence of teacher autonomy on learner autonomy. System, 23(2), 175-181. http://dx.doi.org/10.1016/0346-251X(95)00006-6

Maleki, A. (2007). Teachability of communication strategies: An Iranian experience. System, 4, 583-594. http://dx.doi.org/10.1016/j.system.2007.04.001

Rivers, W. M. (1981). Teaching foreign-language skills (2nd ed.). Chicago: University of Chicago Press.

Rost, M. (1994). Communication strategies: Are they teachable? Paper presented at TESOL'94, Baltimore.

Tarone, E. (1980). Communication strategies, foreigner talk and repair in interlanguage. Language Learning, 30, 417-431. http://dx.doi.org/10.1111/j.1467-1770.1980.tb00326.x

Williems, G. M. (1987). Communication strategies and their significance in foreign language teaching. System, 15, 351-364. http://dx.doi.org/10.1016/0346-251X(87)90009-1

Wright, A. Betteridge, \& Buckby, M. (2002). Games for language learning. Cambridge University Press.

\section{Appendix 1. List of CS categories- Categorized Based on the Purpose of this Study}

\section{A: Paraphrase or Circumlocution}

Explanation:

The student seems not know or cannot recollect the right word for the meaning s/he wishes to convery. $\mathrm{S} / \mathrm{he}$ therefore uses an alternative word or phrase.

Examples :

A.1. Definition: 'A sign for stopping cars' $=($ a halt sign $)$

A.2. Description: It's the green part of the flower (leaf)

\section{B. Approximation}

The student seems not know or cannot recollect the right word for the meaning s/he wishes to convey. $\mathrm{S} / \mathrm{he}$ therefore uses a more general term.

Example:

She's wearing a kind of shoes (sandals)

\section{Hesitation}

The student stops because s/he is aware that they cannot remember or does not know the right word.

\section{Hesitation with fillers}

The student uses typical words and phrases to give themselves time to think about what they are going to say.

\section{Hesitation with retrieval}

The student cannot at first recall the correct word or phrase but continues to reformulate in an effort to reach the correct target phrase.

Example:

C.1. Well..er...I think that.. what do you say...this is a strong problem because

C.2. I was /wok/../wor/.. I was walking

\section{Words which are borrowed, invented or anglicized}

The student does not know or is not sure of the correct form of a word, so uses their L1, possibly anglicizing in a number of ways. Alternatively, the student may invent a word using a similar known expression.

Example:

D.1. Is it a $/$ viorent $/=$ tape-recorder (borrowed from L1)

D.2. There is many /muscot/ (anglicizing L1 for grape)

D.3. (Literal translation)

\section{E. Reduction}

The student would like to communicate something but decides that they do not have the necessary language.

Example

E.1. Oh! I can't say this...let's talk about something else (the students abandons the topic and switches)

E.2. I am sorry I don't know the word. ( the student gives up) 